\title{
Mosaic Turner syndrome with improved Chiari type 1 malformation after growth hormone therapy: A case report
}

\author{
Toshihiko Mori ${ }^{1}$, Ryotaro Shimomura ${ }^{1}$, Mami Iwasa ${ }^{1}$, Takuro Ito ${ }^{1}$, Hyronori lizuka ${ }^{1}$, Emiko Hoshino ${ }^{1}$, \\ Satoshi Hirakawa ${ }^{1}$, Nodoka Sakurai ${ }^{1}$, and Shigeto Fuse ${ }^{1}$ \\ ${ }^{1}$ Department of Pediatrics, NTT East Sapporo Hospital, Sapporo, Japan
}

\begin{abstract}
We described a three-year-old girl whose Chiari type 1 malformation associated with mosaic Turner syndrome disappeared after GH therapy. She was diagnosed with mosaic Turner syndrome at the age of 1 yr and 7 mo by a chromosomal analysis (G-band) for short stature and was treated with GH. Sagittal T1-weighted magnetic resonance imaging (MRI) performed before the start of GH demonstrated herniation of the cerebellar tonsils $7 \mathrm{~mm}$ below the foramen magnum into the cervical spinal cord. After the initiation of GH therapy, the growth in height was favorable and improved from $70.6 \mathrm{~cm}(-3.5 \mathrm{SD})$ to $92 \mathrm{~cm}(-1.5 \mathrm{SD})$ in $2 \mathrm{yr}$. An MRI examination 19 mo later showed the disappearance of Chiari type 1 malformation. GH therapy either exacerbates or ameliorates Chiari type 1 malformations associated with GH deficiency (GHD). Since Turner syndrome uses more GH than GHD, careful follow-up is required if the disease is associated with Chiari type 1 malformation.
\end{abstract}

Key words: Turner syndrome, Chiari type 1 malformation, GH therapy, resolution, MRI

Turner syndrome, caused by partial or complete loss of an X chromosome, is one of the common chromosomal anomalies in humans. It is typically associated with primary amenorrhea due to early ovarian failure and short stature (1). Abnormalities such as malformations in the central nervous system (CNS) are extremely rare in Turner syndrome, with a few complications of CNS symptoms such as epilepsy and mental retardation. To our knowledge, there was only one report of Turner syndrome with Chiari type I malformation by Harsha KJ et al. (2). A Chiari type 1 malformation is a congenital or acquired abnormality of the brainstem, characterized by caudal herniation of cerebellar tonsils through the foramen magnum $(3,4)$. Exacerbation of neurological symptoms occur in patients with GH deficiency (GHD) and concomitant Chiari type 1 malformation during administration of $\mathrm{GH}$ replacement therapy (5-8). GH therapy is also used for Turner syndrome in patients of short stature, at a dose of $0.35 \mathrm{mg} / \mathrm{kg} / \mathrm{wk}$, which is twice the dose of GHD.

Previously, we reported a case of Chiari type 1 malformation and severe sleep apnea after high-dose GH therapy, requiring decompression surgery (9). Therefore, at our institution, before the initiation of GH therapy, head MRI checks are conducted for the presence of Chiari malformation. In this report, we present a case of mosaic Turner syndrome with Chiari type 1 malformation and showed the influence of GH therapy on serial MRI.

\section{Case Report}

A girl aged 1 yr and 7 mo was referred to our hospital because of short stature. She was delivered normally after $41 \mathrm{wk}$ and $5 \mathrm{~d}$ of gestation, and her birth weight and height were $3070 \mathrm{~g}$ and $46 \mathrm{~cm}$, respectively. She demonstrated delayed growth since early childhood. On physical examination, her height was $70.6 \mathrm{~cm} \mathrm{(-3.5}$ SD from the mean for normal Japanese girls). There were no physical findings such as a short neck with webbed appearance, low hairline at the back of the head, lowset ears, and a broad chest with widely spaced nipples suggesting Turner syndrome. Her 3-yr-old sister did not have short stature, and her father's and mother's heights were $180 \mathrm{~cm}$ and $166 \mathrm{~cm}$, respectively. The height potential prediction based on the mid-parental height was $166.5 \mathrm{~cm}$. Laboratory data were generally unremarkable including serum IGF-1, $36 \mathrm{ng} / \mathrm{mL}$; free T4, $1.45 \mathrm{ng} / \mathrm{dL}$; and TSH, 5.37 IU/L. Her chromosomal analysis (G-band) was conducted after obtaining informed consent. Her karyotype was found to be $45, \mathrm{X}$

Received: July 12, 2020 Accepted: August 20, 2020

Corresponding author: Toshihiko Mori, M.D., Department of Pediatrics, NTT East Sapporo Hospital, South-1, West-15, Chuo-ku, Sapporo, Hokkaido 060-0061, Japan

E-mail: toshihiko_mori@east.ntt.co.jp

This is an open-access article distributed under the terms of the Creative Commons Attribution NonCommercial No Derivatives (by-nc-nd) License<http://creativecommons.org/licenses/by-nc-nd/4.0/>. 
[19]/47, XXX [11], suggesting mosaic Turner syndrome. Data pertaining to provocation tests were as follows: peak GH levels $19.8 \mathrm{ng} / \mathrm{mL}$ to insulin and $18.1 \mathrm{ng} / \mathrm{mL}$ to arginine-HCL. Further examination showed no urinary tract or cardiac malformation with normal psychomotor development. T1-weighted images observed on MRI prior to administration of GH therapy, demonstrated herniation of the cerebellar tonsils $7 \mathrm{~mm}$ into the cervical spinal cord below the foramen magnum (Fig. 1). She was observed to be in good general condition without signs of cranial nerve palsy, cerebellar dysfunction, and peripheral motor or sensory nerve deficits. GH therapy was initiated at the age of $1 \mathrm{yr}$ and 8 mo with informed consent because of the risk of deterioration of Chiari type 1 malformation. The initiation dose was 0.175 $\mathrm{mg} / \mathrm{kg} / \mathrm{wk}$, which was increased to $0.35 \mathrm{mg} / \mathrm{kg} / \mathrm{wk} 3 \mathrm{mo}$ later. She responded well to GH therapy and her height increased by $9.9 \mathrm{~cm}$ in the first $9 \mathrm{mo}$ (Fig. 2). There was no significant change in MRI at this point, and spinal MRI showed no evidence of syringomyelia (Fig. 3a, b). A year later, her height was $92 \mathrm{~cm}(-1.5 \mathrm{SD})$ and an MRI scan showed a marked improvement in Chiari type 1 malformation (Fig. 4).

\section{Discussion}

Turner syndrome is a rare chromosomal abnormality affecting females. It is characterized by the partial or complete loss (monosomy) of one of the second $\mathrm{X}$ chromosomes in some or all cells. Turner syndrome is highly variable among individuals with affected

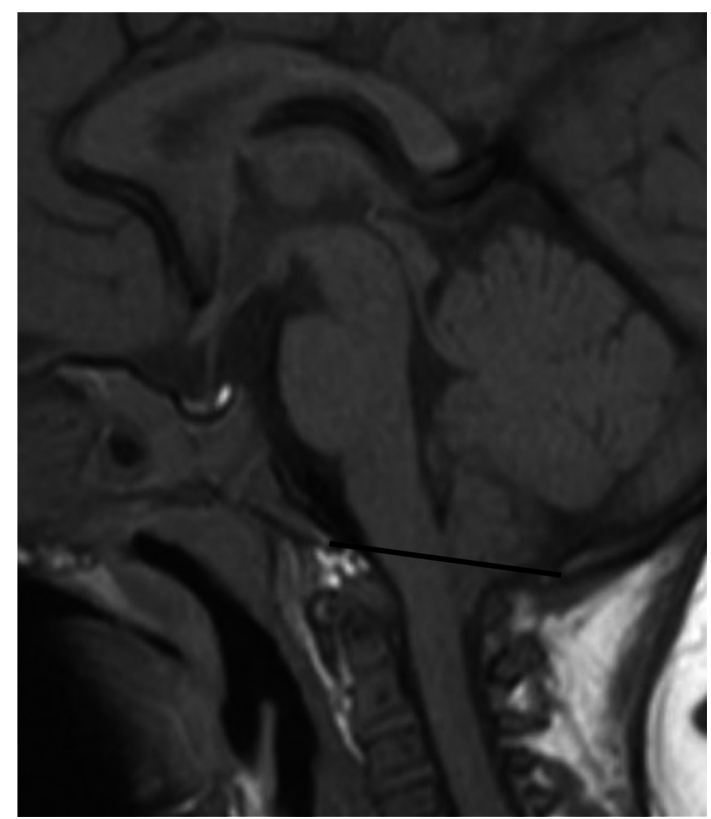

Fig. 1. Sagittal T1-weighted magnetic resonance imaging (MRI) prior to GH therapy showing herniation of the cerebellar tonsils $7 \mathrm{~mm}$ below the foramen magnum (black line) into the cervical spinal cord. Posterior fossa appears crowded with effacement of cerebrospinal fluid (CSF) spaces. patients developing a wide variety of symptoms, affecting different organ systems. The common symptoms include short stature and premature ovarian failure making it impossible to reach puberty (1). The clinical phenotype of females with mosaicism for a normal cell line is often milder than that seen in $45, \mathrm{X}$ patients, although this depends on the affected tissues and the timing of development of the mosaicism. In this case, there were no physical findings of Turner syndrome other than short stature. Gross congenital abnormalities of CNS in Turner syndrome are rare, and only a few cases are reported in the literature. To our knowledge, there was only a single report of Turner syndrome with Chiari type 1 malformation by Harsha KJ et al. (2).

A Chiari type 1 malformation is characterized by caudal herniation of the cerebellar tonsils through the foramen magnum. The herniated tonsils compress the brainstem and block the normal flow of cerebrospinal fluid. A Chiari type 1 malformation is commonly associated with cervical syringomyelia and typically presents with neurological symptoms in adults, such as headache, neck pain, ataxia, cranial nerve palsies, and sensory deficits $(3,4)$. Chiari type 1 malformations are diagnosed in adolescents and adults using an MRI where single or both cerebellar tonsils are observed to be displaced by $\geq 5 \mathrm{~mm}$ below the foramen magnum (10). The effect of GH therapy on Chiari type 1 malformation

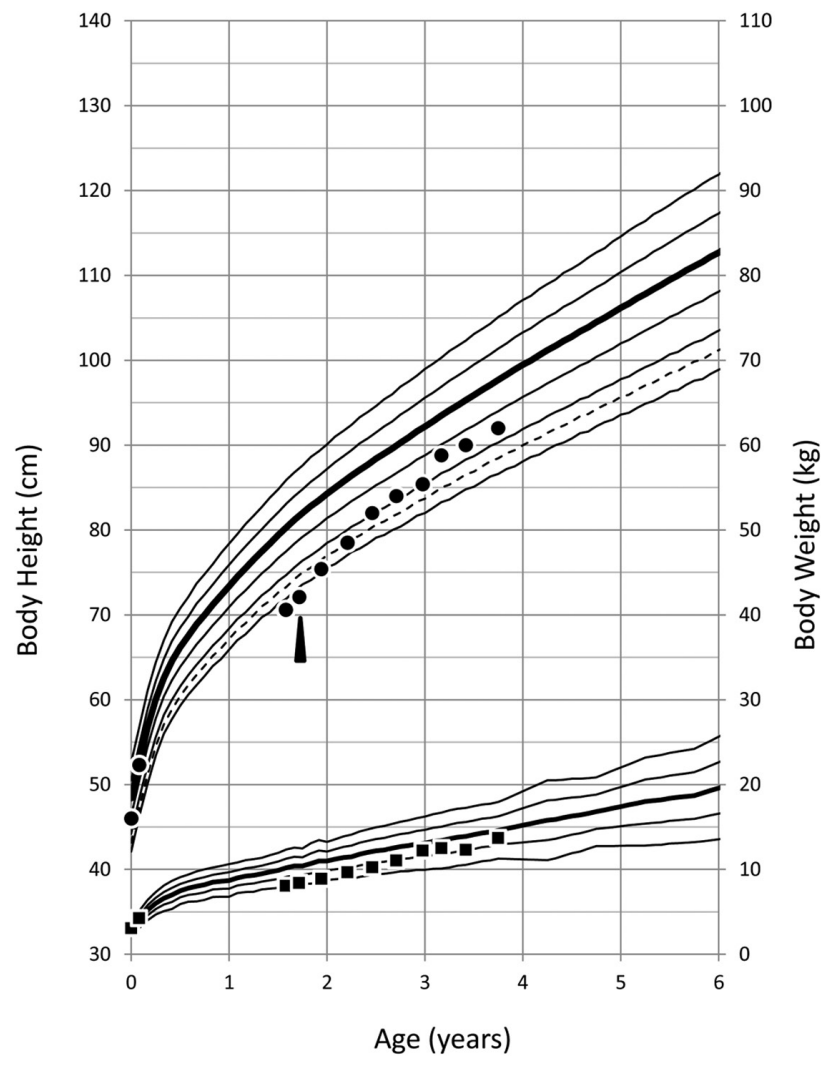

Fig. 2. Growth chart of the patient. Closed circles indicate height and closed squares indicate weight. The arrowhead indicates the time when GH therapy was initiated. 

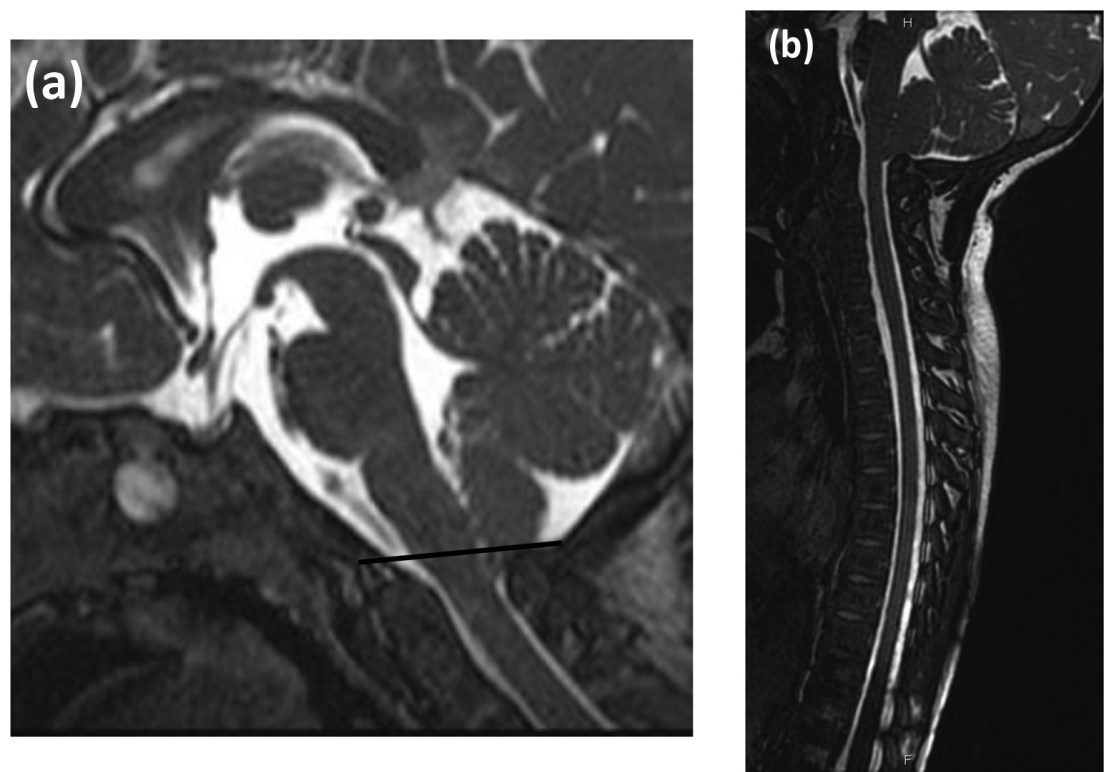

Fig. 3. (a) Sagittal fast imaging employing steady-state acquisition (FIESTA) magnetic resonance imaging (MRI) 9 mo after GH therapy showing no significant changes in the Chiari type 1 malformation. (b) Sagittal FIESTA MRI of the entire spinal cord does not show syringomyelia. The black line indicated the foramen magnum.

associated with GHD is controversial. Some studies have documented clinical decline in patients while on hormone replacement therapy (5-8), whereas others have reported resolution of the radiologic findings after initiating medical therapy (11). Spontaneous resolution of Chiari type 1 malformation in patients without GHD has also been reported $(12,13)$.

Regarding the incidence of GHD in patients with Chiari type 1 malformation, Ballard $\mathrm{H}$ et al. (14) recently reported $4.3 \%$ of their Chiari malformation patient population $(\mathrm{N}=456)$ with GHD. They described 20 patients with Chiari type 1 malformation and GHD, where 14 patients received GH replacement therapy and six did not. They described that none of the patients with Chiari type 1 malformation and GHD, with or without GH replacement therapy regardless of the change in Chiari type 1 malformation measurement, developed symptoms or syringomyelia, or required surgical intervention (14). Although a subsequent additional report corrected the requirement of decompression surgery in one patient, they concluded, as previously, that the presence of a Chiari type 1 malformation should not prevent initiation of GH therapy (15).

In this case, a Chiari type 1 malformation was found by MRI before the initiation of GH therapy. In our facility, when performing head MRI to detect the cause of short stature before initiation of GH therapy, a sagittal section is taken to check for the presence of a Chiari malformation. In addition to GHD, GH therapy is used for conditions such as Prader-Willi syndrome (PWS), achondroplasia, Noonan's syndrome, and Turner syndrome. Serious adverse events from GH therapy have been reported in PWS. GH therapy is known to produce multiple beneficial effects on growth and body composition, as well as motor and mental development

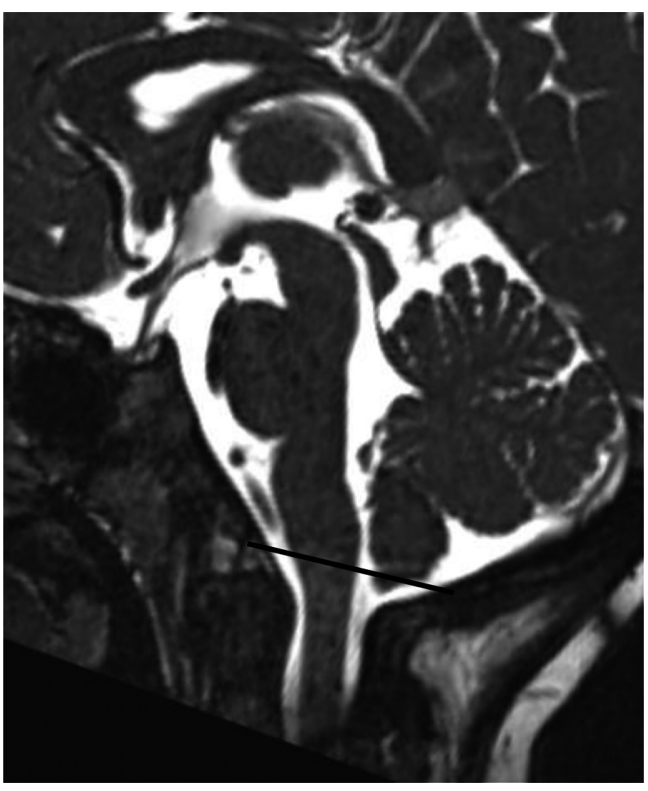

Fig. 4. Sagittal fast imaging employing steady-state acquisition (FIESTA) magnetic resonance imaging (MRI) 19 mo after GH therapy showing marked improvement in the Chiari type 1 malformation. Posterior fossa no longer appears crowed and CFS spaces are visible. The black line indicated the foramen magnum.

in patients diagnosed with PWS. Although Chiari malformations are not clarified, sudden death is known to occur during GH therapy in PWS patients, with 28 such deaths reported globally $(16,17)$. There have been some reports of Chiari type 1 malformation associated with Noonan's syndrome, a close morphological mimicker of Turner syndrome, without reporting the use 
of GH (18). Regarding the mechanism of exacerbation/ improvement of Chiari malformation in GH therapy, differential growth between bony structures (skull and vertebral column) and the CNS might have been responsible for the development of the malformation, with spontaneous remission or deterioration depending on the growth balance. There is no conclusive evidence regarding the efficacy of hormone replacement on the Chiari type 1 malformation in children with GHD. Moreover, there is no way to predict which patients will improve versus progress. Although Turner syndrome is seldom associated with Chiari type 1 malformations, if present, careful follow-up is required, as the dose of $\mathrm{GH}$ used is $0.35 \mathrm{mg} / \mathrm{kg} / \mathrm{wk}$, which is twice the dose of GHD.

Diagnosis of Chiari type 1 malformation is often delayed until symptoms become severe or persistent.
Complications such as central sleep apnea are serious risk factors associated with sudden death syndrome. An accurate diagnosis and prompt treatment prevent permanent injury to the nervous system. Chiari type 1 malformations may be exacerbated or ameliorated due to the relationship between posterior fossa and brain (cerebellum) volume. Although the natural course of asymptomatic pediatric Chiari type 1 malformation with or without syringomyelia is more favorable than that previously acknowledged (19), patients treated with GH replacement therapy should be followed closely with serial imaging and clinical assessments for evidence of progression. High doses of GH could be used for patients with Chiari type 1 malformation, if followed by careful monitoring of head MRI.

1. Wolff DJ, Van Dyke DL, Powell CM, Working Group of the ACMG Laboratory Quality Assurance Committee. Laboratory guideline for Turner syndrome. Genet Med 2010;12: 52-5. [Medline] [CrossRef]

2. Harsha KJ, Nair JS. Chiari I malformation associated with Turner syndrome. J Neurosci Rural Pract 2017;8: 277-80. [Medline] [CrossRef]

3. Greenlee JDW, Donovan KA, Hasan DM, Menezes AH. Chiari I malformation in the very young child: the spectrum of presentations and experience in 31 children under age 6 years. Pediatrics 2002;110: 1212-9. [Medline] [CrossRef]

4. Tubbs RS, McGirt MJ, Oakes WJ. Surgical experience in 130 pediatric patients with Chiari I malformations. J Neurosurg 2003;99: 291-6. [Medline] [CrossRef]

5. Fujita K, Matsuo N, Mori O, Koda N, Mukai E, Okabe Y, et al. The association of hypopituitarism with small pituitary, invisible pituitary stalk, type 1 Arnold-Chiari malformation, and syringomyelia in seven patients born in breech position: a further proof of birth injury theory on the pathogenesis of "idiopathic hypopituitarism". Eur J Pediatr 1992;151:266-70. [Medline] [CrossRef]

6. Takakuwa S, Asai A, Igarashi N. A case of syringomyelia with type I Arnold-Chiari malformation (ACM): growth hormone (GH) therapy and the size of syrinx on serial MR images. Endocr J 1996;43(Suppl): S129-30. [Medline] [CrossRef]

7. Naftel RP, Tubbs RS, Menendez JY, Oakes WJ. Progression of Chiari I malformations while on growth hormone replacement: a report of two cases. Childs Nerv Syst 2013;29: 2291-4. [Medline] [CrossRef]

8. O'Grady MJ, Cody D. Symptomatic Chiari 1 malformation after initiation of growth hormone therapy. J Pediatr 2011;158: 686. [Medline] [CrossRef]

9. Mori T, Nishino E, Jitsukawa T, Hoshino E, Hirakawa S, Kuroiwa Y, et al. Chiari type 1 malformation associated with central sleep apnea after high dose growth hormone (GH) therapy in a 12-year-old boy: A case report. Clin Pediatr Endocrinol 2018;27: 45-51. [Medline] [CrossRef]

10. Elster AD, Chen MY. Chiari I malformations: clinical and radiologic reappraisal. Radiology 1992;183:347-53. [Medline] [CrossRef]

11. Gupta A, Vitali AM, Rothstein R, Cochrane DD. Resolution of syringomyelia and Chiari malformation after growth hormone therapy. Childs Nerv Syst 2008;24: 1345-8. [Medline] [CrossRef]

12. Avellino AM, Kim DK, Weinberger E, Roberts TS. Resolution of spinal syringes and Chiari I malformation in a child. Case illustration. J Neurosurg 1996;84: 708. [Medline] [CrossRef]

13. Avellino AM, Britz GW, McDowell JR, Shaw DW, Ellenbogen RG, Roberts TS. Spontaneous resolution of a cervicothoracic syrinx in a child. Case report and review of the literature. Pediatr Neurosurg 1999;30: 43-6. [Medline] [CrossRef]

14. Ballard H, Fuell W, Elwy R, Lou XY, Albert GW. Effects of growth hormone therapy in pediatric patients with growth hormone deficiency and Chiari I malformation: a retrospective study. Childs Nerv Syst 2020;36: 835-9. [Medline] [CrossRef]

15. Albert GW. Effects of growth hormone therapy in pediatric patients with growth hormone deficiency and Chiari I malformation: a retrospective study. Childs Nerv Syst 2020;36: 667. [Medline] [CrossRef]

16. Aycan Z, Baş VN. Prader-Willi syndrome and growth hormone deficiency. J Clin Res Pediatr Endocrinol 2014;6: 62-7. [Medline] [CrossRef]

17. Eiholzer U. Deaths in children with Prader-Willi syndrome. A contribution to the debate about the safety of growth hormone treatment in children with PWS. Horm Res 2005;63: 33-9. [Medline]

18. Keh YS, Abernethy L, Pettorini B. Association between Noonan syndrome and Chiari I malformation: a case-based update. Childs Nerv Syst 2013;29: 749-52. [Medline] [CrossRef]

19. Chatrath A, Marino A, Taylor D, Elsarrag M, Soldozy S, Jane Jr JA. Chiari I malformation in children-the natural history Childs Nerv Syst 2019;35: 1793-9. [Medline] [CrossRef] 